\title{
Ankyloblepharon filiforme adnatum
}

\author{
C. H. AKKERMANS AND L. M. STERN \\ From the Adelaide Children's Hospital Inc.
}

SUMmaRY Two cases of ankyloblepharon filiforme adnatum in siblings are presented. One sib had associated cleft lip and palate, the other had bilateral syndactyly of the second and third toes. Father, paternal grandmother, and great-grandmother all had bilateral syndactyly of the second and third toes. Cases of ankyloblepharon filiforme adnatum reported in the ophthalmic literature are reviewed as are cases of ankyloblepharon occurring as part of the popliteal pterygium syndrome. It is postulated that the association of ankyloblepharon with other abnormalities may be part of the spectrum of the popliteal pterygium syndrome with autosomal dominant inheritance, incomplete penetrance, and variable expressivity.

Ankyloblepharon filiforme adnatum (AFA) is a rare benign congenital abnormality. A more than chance association with other congenital abnormalities and occurrence in siblings make the study of pedigrees of affected individuals of interest in trying to ascertain the heritability of the condition.

\section{Case report}

This girl was born on August 6 1977, the result of a normal full-term pregnancy. Her mother denied taking any drugs during the first trimester. At birth the baby was noted to have 'fused' eyelids as well as bilateral cleft lip and palate (Fig. 1a, b). Cardiac auscultation revealed a systolic murmur which disappeared by the second day and was thought to represent a closing ductus arteriosus.

More detailed ophthalmic examination showed that there were 2 asymmetrical adhesions between each pair of eyelids; these were easily parted with a strabismus hook. The manoeuvre was accompanied by minimal bleeding along the grey line of each eyelid (Fig. $2 a, b$ ). The vestigial remnants on the eyelid margins disappeared completely within 48 hours. The cilia and posterior surface of each eyelid were normal, as were the eyes to external examination, ophthalmoscopy, and retinoscopy. Chromosome analysis revealed a normal female karyotype.

The family history had no records of consanguinity. An older brother born on August 191973 had bilateral AFA as well as bilateral syndactyly of

Address for reprints: Dr C. Akkermans, Adelaide Children's Hospital Inc., 72 King William Road, North Adelaide 5006, South Australia, Australia the second and third toes. The eyelid adhesions were freed by the family physician. There were no other ocular abnormalities. The father has no ocular abnormalities but has similar bilateral syndactyly of the second and third toes. The mother is myopic but is otherwise normal. The paternal grandmother and great grandmother both had bilateral syndactyly of the second and third toes.

\section{Discussion}

Ankyloblepharon filiforme adnatum was first described by von Hasner in 1881 (Judge et al., 1929). It occurs in many cases as an isolated anomaly, and the bands may be single or multiple (Duke-Elder, 1964). Associated anomalies have included cleft lip and palate (Khanna, 1957; Long and Blandford, 1962; Sood et al., 1968; Ehlers and Jensen, 1970). Neuman and Shulman (1961) described a 3-day-old boy with AFA who had in addition adhesions between the alveolar processes of both upper and lower jaws, a papilla and a sinus on the left side of the lower lip, and a cleft palate. Bilateral syndactyly of the fourth and fifth toes, partial adherence of the left ear to the skin of the head, and a ventricular septal defect of the membranous type with a patent ductus arteriosus were associated abnormalities reported by Rogers (1961) in a premature baby. More recently Kazarian and Goldstein (1977) have reported a single case of AFA associated with hydrocephalus, meningomyelocele, and imperforate anus.

The histological changes of AFA have been described by many authors; the cause, however, has not been elucidated. A 'familial' tendency was invoked by Howe and Harcourt (1974), who 


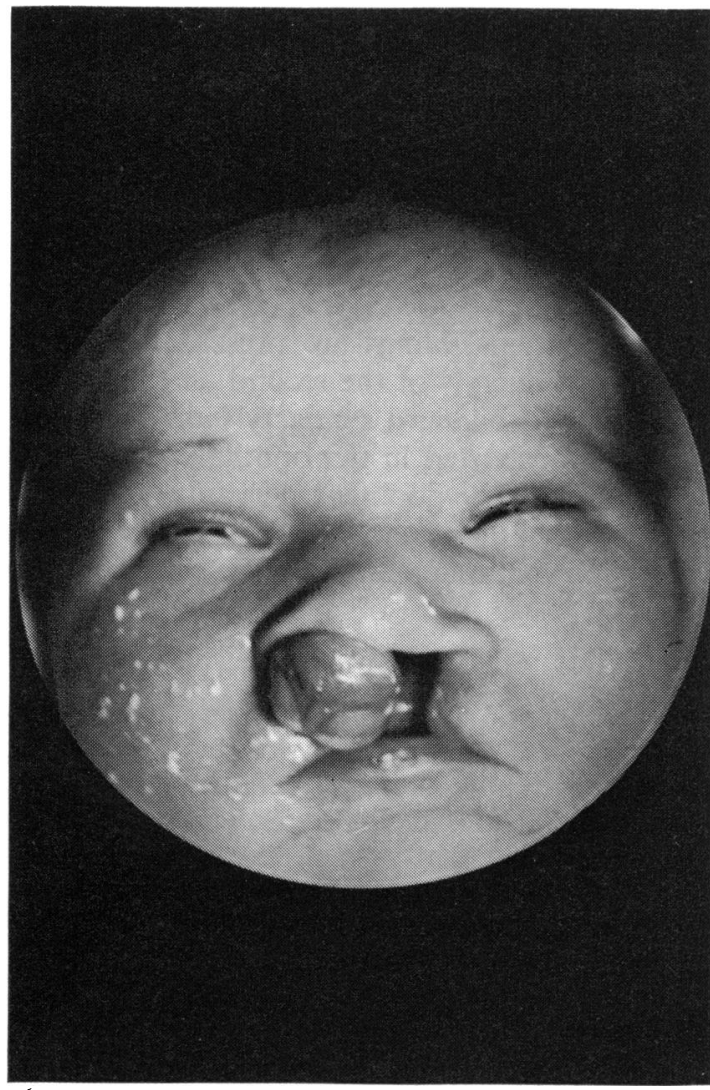

Fig. 1a Bilateral AFA and cleft lip

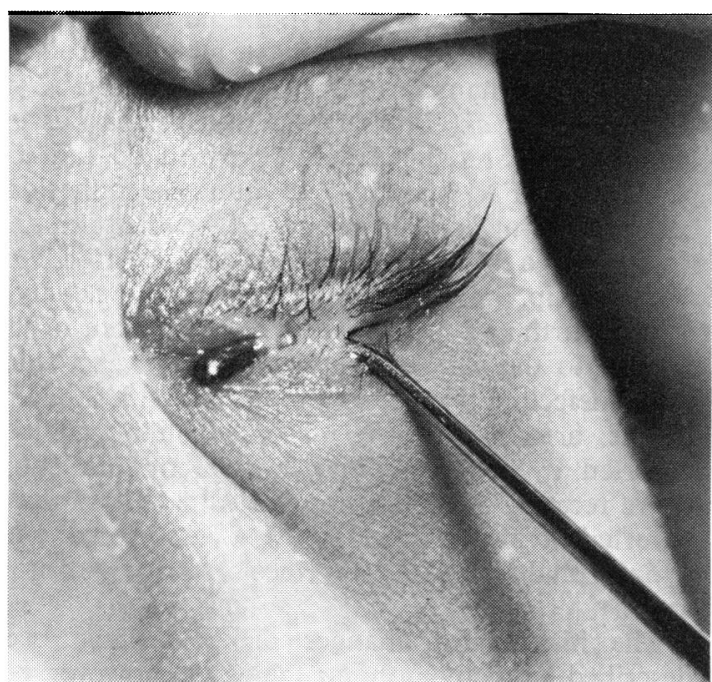

Fig. 2a Strabismus hook in place prior to separation of left eyelid adhesions

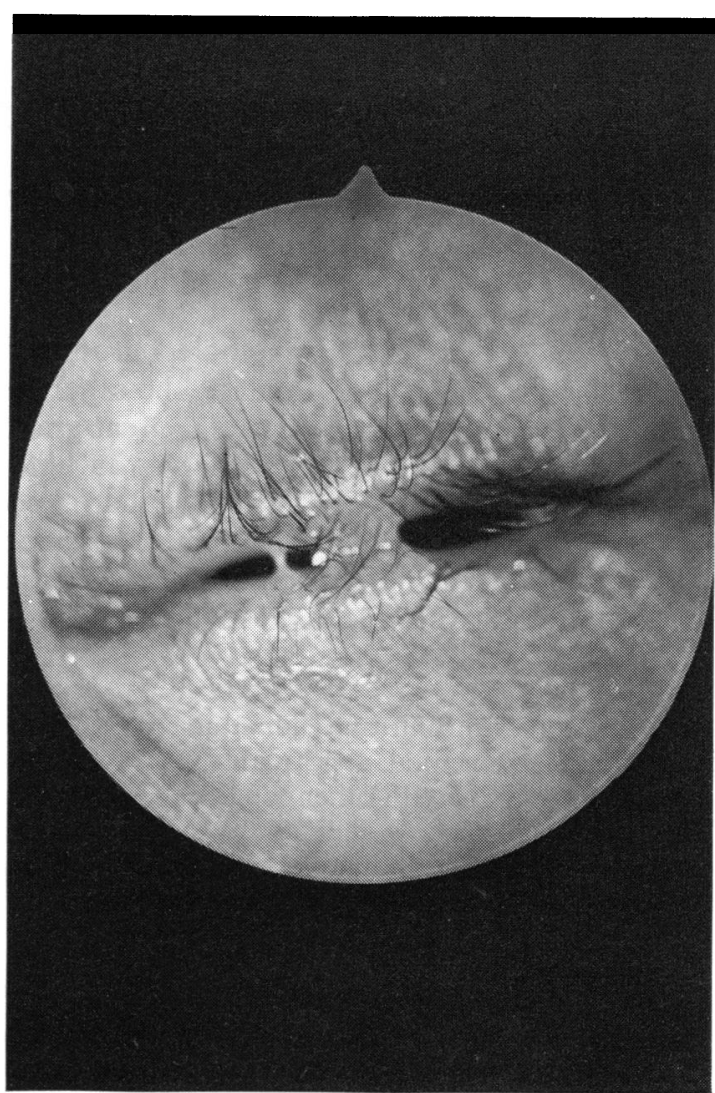

Fig. 1b Close-up of adhesions of left eyelids

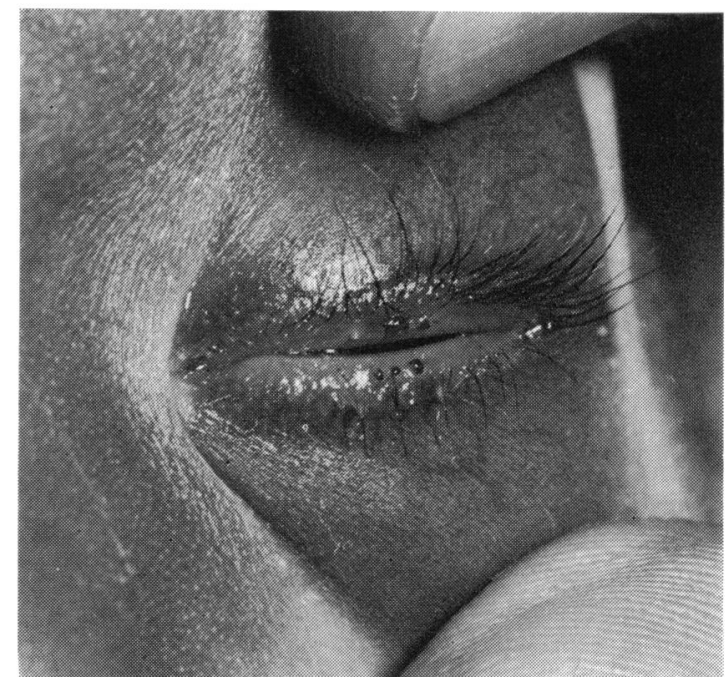

Fig. $2 \mathrm{~b}$ Left eyelids showing minimal bleeding along the grey line following separation 
described the condition in identical twins, and by Khanna (1957), who reported the condition in sisters, one of whom had cleft lip and palate. Gorlin et al. (1971) stated that 'the association of cleft lip or cleft palate or both and congenital filiforme fusion of the eyelids appears to be inherited as an autosomal dominant trait'.

AFA may occur as part of the popliteal pterygium syndrome. Other features of this syndrome include popliteal pterygia and oral, skeletal, digital, and genitourinary anomalies. Hecht and Jarvinen (1967) described 2 families in whom a mother and 2 of her children were affected. They noted wide variability of expression of the syndrome and postulated autosomal dominant inheritance. Gorlin et al. (1968) also suggested that the syndrome was inherited as an autosomal dominant trait with incomplete penetrance and variable expressivity. The same view was expressed in a recent phenotypic and genetic analysis of the popliteal pterygium syndrome by Escobar and Weaver (1978). They reviewed a number of pedigrees and stressed that the few documented familial cases showed a wide variation in gene expression in affected relatives.

We suggest that virtually all the cases of AFA reported in the ophthalmic literature as well as our own 2 cases may be part of the spectrum of the popliteal pterygium syndrome. Like other authors we suggest an autosomal dominant inheritance with incomplete penetrance and variable expressivity. This would have important implications in genetic counselling of the parents of affected offspring.

\section{References}

Duke-Elder, S. (1964). System of Ophthalmology, vol. 3, part 2, p. 869. Henry Kimpton: London.

Ehlers, N., and Jensen, I. K. (1970). Ankyloblepharon filiforme congenitum associated with harelip and cleft palate. Acta Ophthalmologica, 48, 465-467.

Escobar, V., and Weaver, D. (1978). Popliteal pterygium syndrome: a phenotypic and genetic analysis. Journal of Medical Genetics, 15, 35-42.

Gorlin, R. J., Sedano, H. O., and Cervenka, J. (1968). Popliteal pterygium syndrome. Pediatrics, 41, 503-509.

Gorlin, R. J., Cervenka, J., and Pruzansky, S. (1971). Facial clefting and its syndromes. Birth Defects: Original Article Series, 7, 15.

Hecht, F., and Jarvinen, J. M. (1967). Heritable dysmorphic syndrome with normal intelligence. Journal of Pediatrics, 70, 927-935.

Howe, J., and Harcourt, B. (1974). Ankyloblepharon filiforme adnatum affecting identical twins. British Journal of Ophthalmology, 58, 630-632.

Judge, H. V., Mott, W. C., and Gabriels, J. A. C. (1929). Ankyloblepharon filiforme adnatum. Archives of Ophthalmology, 2, 702-708.

Kazarian, E. L., and Goldstein, P. (1977). Ankyloblepharon filiforme adnatum with hydrocephalus, meningomyelocele, and imperforate anus. American Journal of Ophthalmology, 84, 355-357.

Khanna, V. N. (1957). Ankyloblepharon filiforme adnatum. American Journal of Ophthalmology, 43, 774-777.

Long, J. C., and Blandford, S. E. (1962). Ankyloblepharon filiforme adnatum with cleft lip and palate. American Journal of Ophthalmology, 53, 126-129.

Neuman, Z., and Shulman, J. (1961). Congenital sinuses of the lower lip. Oral Surgery, 14, 1415-1420.

Rogers, J. W. (1961). Ankyloblepharon filiforme adnatum. Archives of Ophthalmology, 65, 114-117.

Sood, N. N., Agarwal, T. P., and Ratnaraj, A. (1968). Ankyloblepharon filiforme adnatum with cleft lip and palate. Journal of Pediatric Ophthalmology, 5, 30-32. 